\title{
Reproductive development of the priapium fish Neosthetus lankesteri Regan, 1916 (Atheriniformes: Phallosthethidae) from Pranburi river estuary, Thailand using the histological approach
}

\author{
Amphornphan Palasai ${ }^{a}$, Sinlapachai Senarat ${ }^{\mathrm{b}}$, Phakorn Na Lampang ${ }^{\mathrm{a}}$, Niwat Kangwanrangsan ${ }^{\mathrm{c}}$, \\ Wannee Jiraungkoorskul ${ }^{c}$, Diógenes Henrique de Siqueira-Silva ${ }^{\mathrm{d}}$, Jes Kettratad ${ }^{\mathrm{a}, \mathrm{e}}$ \\ ${ }^{a}$ Department of Marine Science, Faculty of Science, Chulalongkorn University, Bangkok 10330, Thailand \\ ${ }^{b}$ Department of Marine Science and Environment, Faculty of Science and Fisheries Technology, Rajamangala University of Technology \\ Srivijaya, Trang 92150, Thailand \\ 'Department of Pathobiology, Faculty of Science, Mabidol University, Bangkok 10400, Thailand \\ ${ }^{d}$ Group of Studies on the Reproduction of Amazon fish (GERPA/LANEC), PPG in Biodiversity and Biotechnology (BIONORTE), \\ University of South and Southern of Pará (Unifesspa), Marabá, Pará, Brazil \\ ${ }^{\circ}$ Marine Ecology and Marine Resources Utilization Research Unit, Aquatic Resources Research Institute, Chulalongkorn University, \\ Bangkok 10330, Thailand
}

Received 9th December 2019 / Accepted 10th May 2020

\begin{abstract}
Reproduction in the family Phallostethidae is an area that has long been of interest especially in gonadal structure and gametogenesis. However, no published data concerning as mentioned above in Neostethus lankesteri Regan, 1916 from Thailand is noted. This fish is important for rural livelihood in the estuarine fisheries of Pranburi River estuary, Thailand. The construction of the female reproductive system of $N$. lankesteri composed of the ovary and short oviduct. The mature ovarian morphology is a single organ, which is histologically considered to be an asynchronous development ovary. The differentiating oocytes were observed and classified into oogonia proliferation, primary growth phase, secondary growth phase, post-ovulatory phase and atretic follicle phase. Under the ovarian differentiation, our observation indicated that the ovarian parenchyma of $N$. lankesteri during $1.8-2.4 \mathrm{~cm}$ in standard length (SL) was accompanied by the secondary growth phases. Identification of the post-ovulatory phase was detected during our sampling periods, indicating to entire life in the Pranburi River estuary as well as true resident species. In the male reproductive system of $N$. lankesteri, the mature testicular parenchyma was organized morphologically as a single organ and histologically appeared to be a restricted spermatogonial lobular testis type. The differentiation of the spermatogenetic stage was composed of three phases including spermatogonial, spermatocyte and spermiogenetic phases. It was to identify possible trends that the size at first maturity of the female fish was estimated at $1.8 \mathrm{~cm} \mathrm{SL}$. Certainly, results from this study clearly showed on the reproductive pattern of $N$. lankesteri, which could be applied to further studies (the reproductive cycle, spawning season and histopathology).
\end{abstract}

Keywords: fish, histology, oogenesis, phallostethidae, reproduction

\section{INTRODUCTION}

Considering that the aspects of reproduction in fish has been wildly reported, it is quite important to accurately determine the physiological and biological process, such gametogenesis, that occur

*Author for correspondence: Jes Kettratad, Department of Marine Science, Faculty of Science, Chulalongkorn University, Bangkok 10330, Thailand. Email-Jes.K@chula.ac.h, kettratadjes@gmail.com 
in their gonads, in order to have effective reproductive strategies and fisheries management (Mayer et al., 1998). Light microscopy has been used by many researchers in order to describe gonadal structure, development and gametogenesis in a variety of teleost (Mayer et al., 1988). These include Fundulus beteroclitus (Kuchnow and Scott, 1977), Oryzias latipes (Wallace and Selman, 1981), Dicentrachus labrax (Mayer et al., 1988), Centropomus undecimalis (Neidig et al., 2000), Tragopogon orientalis (Chen et al., 2006) and Serra spanish (Chellappa et al., 2010).

The oogenesis is generally produced within the ovigerous fold, which has been divided into three stages according to their histological structures: immature oocyte, maturing oocyte and mature oocyte. Moreover, the oogenic stage is classified by the uptake of vitellogenin or yolk protein: previtellogenic, vitellogenic and postvitellogenic or mature stage (Gupta, 1975). Gupta (1975) and Uribe et al. (2012) also reported differentiating stage of oocytes (chromatinnucleolus stage, primary growth stage and secondary growth stage).

In male fish, there have been many studies about testicular structure and spermatogenesis (Uribe et al., 2014) such as Scomber. japonicus (Hara and Okiyama, 1998; Mattei, 1991), Xenentodon cancila (Chakrabari and Banerjee, 2015) and Rastrelliger brachysoma (Senarat et al., 2018). The testicular parenchyma was classified into two compartments: interstitial compartment and germinal compartment having numerous convoluted seminiferous structures. The various developmental stages of spermatogenic cells are produced in the seminiferous tubule. Basically, the process of spermatogenesis could be didactically divided into three distinct stages: spermatogonial, meiotic and spermiogesis (Schulz et al., 2010).

Although, there have been reports concerning the gametogenesis in family Phallostethidae such as Phallostethus dunckeri, Neostethus bicornis, Gulaphallus bikolanus (Grier and Parenti, 1994; Mok and Munro, 1997; Parenti and Grier, 2004), none included the priapium fish, Neostethus lankesteri (Regan, 1916) from Thailand. This fish is reported as a dominant species and is an important estuarine fish in the Pranburi River estuary, Thailand (Paphavasit et al., 2014). Because $N$. lankesteri was categorized to be zooplankton feeder, it was previously believed to play an important role in linking the secondary consumer under the ecological system (Paphavasit et al., 2014). Additionally, a unique characterization of members from the family Phallostethidae is the presence of a secondary reproductive organ called "the priapium organ". This organ is modified from the pelvic fin (Parenti, 1984), and it plays a role in the transfer of spermatozoa from the male to the female reproductive tract and laid Sticky eggs on the substrate. In addition, female do not give birth to live young but instead lay fertilized eggs (Grier and Parenti, 1994). In this study, mature reproductive pattern and female reductive development of $N$. lankesteri, using histological and histochemical approaches were determined. A better comprehension of the gametogenic process of this species can provide important information before beginning to assess the spawning season, reproductive cycle and histopathology.

\section{MATERIALS AND METHODS}

Forty-five healthy without lesion and the parasitic infection, $N$. lankesteri females $[1.5$ to $2.4 \mathrm{~cm}$, standard length (SL)] were collected by larval fish otter trawl (size $0.505-\mathrm{mm}$ ) from two study sites (the Pranburi River estuary [ST1] and Sirinaj Rajini Mangrove Ecosystem Learning Center [ST2]), Prachuap Khiri Khan Province $\left(12^{\circ} 24^{\prime} 21.6^{\prime \prime} \mathrm{N}, 099^{\circ} 58^{\prime} 37.1^{\prime \prime} \mathrm{E}\right.$ and $12^{\circ} 23^{\prime} 53.77^{\prime \prime}$ N, 099 58'55.98" E), Thailand, in March 2015 (Figure 1). Five fish per size range $(<1.5 \mathrm{~cm}, 1.6-$ $1.7 \mathrm{~cm}, 1.8-1.9 \mathrm{~cm}, 2.0-2.2 \mathrm{~cm}$ and $2.3-2.4$ $\mathrm{cm}$, total specimens $=25$ samples) were collected for the study of oogenic development.

To assess the reproductive pattern, ten male and ten female fish with a SL of $2.4 \mathrm{~cm}$ were collected then euthanized by rapid-cooling shock (Wilson et al., 2009). The reproductive organs were dissected out and anatomically observed under a stereomicroscope. Then, the samples were routinely processed according to standard histological techniques (Presbell and Schreibman, 1997; Suvarna et al., 2013). All paraffin blocks were sectioned at a thickness of $4-5 \mu \mathrm{m}$ and stained with haematoxylin-eosin (H\&E), Alcian blue (AB) and Periodic Acid Schiff (PAS). The 
feature of the gonadal structure and ovarian development were observed and photographed under a light microscope (Leica digital 750). Schematic diagram of the ovarian differentiation was illustrated with Adobe Illustrator CS6.

To investigate the interstitial tissue and Sertoli cell, small pieces of testicular tissue (approx. 1 $\mathrm{mm}^{3}$ in size, $\mathrm{n}=5$ of $2.4 \mathrm{SL}$ ) were collected, which were cut and prefixed in 2.5\% glutaraldehyde (phosphate buffer $\mathrm{pH} 7.3$ ) for $24 \mathrm{~h}$ at $4^{\circ} \mathrm{C}$ and post fixed in $1 \%$ osmium tetroxide. The samples were processed and embedded in epoxy resin (Epon 812). The plastic blocks were cut at a thickness of $90 \mathrm{~nm}$ and stained with uranyl acetate and lead citrate. The thin sections were observed with a JEM-2100 $(200 \mathrm{kV})$ transmission electron microscope (TEM, JEOL, Japan).

\section{RESULTS AND DISCUSSION}

\section{Female reproductive pattern}

Females of $N$. lankesteri have a single ovary within the abdominal cavity that is longitudinally observed below the liver and intestine (Figure 2a). According to morphology and light microscopic level, the ovary is surrounded by an ovarian wall (Figures 2b-2c). Within the ovarian parenchyma, the structure of ovigerous folds were difficult to classify. The ovarian tissue contained several developmental stages of oocytes (Figures 2-4), with this feature being considered as an asynchronous developmental type (Figures 2c2d). This was similar to Neostethus bicornis and Phenacostethus smithi (Mok and Munro, 1996).

The oviduct of this fish is divided into two regions based on localization and histological structure; primary and secondary oviducts (Figures 2e-g and schematic diagram 2a. The primary oviduct was observed in the middle area (dorso-ventral axis) of the ovary (Figures $1 \mathrm{~b}$ and 1d), whereas the secondary continued with the primary oviduct in the posterior part (Figure. $2 \mathrm{~h}$ ). This is in contrast to the salmonids (family Salmonidae) which lack an oviductal structure (Gupta, 1975; Redding and Patino, 2000). Histologically, all oviductal regions were composed of tunica mucosa, tunica muscularis and tunica serosa. Slight irregular folds of the tunica mucosa in the primary oviduct were clearly lined by a simple columnar epithelium (Figure 2e). The mucous secretory cells are spherical shape and rarely seen (Figure 2e). Previous studies reported that the role of the mucous secretory cells are related to the chemical composition of the semen and that it support gametes during transport (Mcmillan, 2007). The primary oviduct was also surrounded by a thin muscularis layer (Figure 2e). The histological structure of the secondary oviduct was different from the primary oviduct. As the primary oviduct, it was also covered by a simple columnar epithelium. Two muscularis layers, including circular and longitudinal ones were obviously identified in this region (Figure 2g). Tunica muscularis is possibly involved in the movement of the oviduct structure during the ovulation process (Chellappa et al., 2010).

In the present study, five phases of female germ cell development were identified in $N$. lankesteri. Those phases were classified according to staining of sections, homogeneity and histological features germ cells into oogonia proliferation, primary growth phase, secondary growth phase, post-ovulatory phase and atretic follicle phase. This is similarly seen in several phallostethid fishes such as Neostethus bicornis and Phenacostethus smithi (Mok and Munro, 1996).

\section{Oogonia proliferation}

The oogonium was the smallest cell among the oogenic cells. It was located in the germinal epithelium (Figure 3a). It is an oval cell. A spherical nucleus shape contained a prominent nucleolus and slight eosinophilic cytoplasm (Figure 3a). The oogonium was formed within clusters or oogonial cysts inside the ovigerous fold. The oogonium was surrounded by a single layer of pre-follicular cells (Figure 3a).

\section{Primary growth phase}

This phase consisted of two sub-stages of oocytes in the mature ovaries including perinucleolar $(\mathrm{Pn})$ and oil droplets, and cortical alveolar stage (Oc). The size of Pn was about $20 \mu \mathrm{m}$ in diameter in $N$. lankesteri. The central nucleus was spherical and large (Figures 3a-3b). Multiple nucleoli with varying diameters were positioned adjacent to the nuclear membrane (Figures 3a-3b). The first appearance of Balbiani's bodies were observed in this stage (Figure 3a), as found in other fishes such 
as mackerel (Wallace and Selman, 1981). The function of Balbiani's body was unclear, but it was believed to be involved in the primary oogenic process because its structure have more complex organelle functions (rich in nucleic acid, RNA and proteins, mitochondria, centrioles, Golgi bodies, and endoplasmic reticulum) (Selman and Wallace, 1989; Hamaguchi, 1993). A strong basophilic staining of the ooplasm was also seen. The presence of basophilic ooplasm during the primary growth stage is a characteristic of intense RNA syntheses together with ribosome production to support oocytes development (Wallace and Selman, 1990). The Oc reached 71 $\mu \mathrm{m}$ in diameter in $N$. lankesteri. The nucleus increased in size during this stage (Figure 3c). The nucleoli at the periphery of the slight folding nucleus were increasingly seen in numbers (7-8 nucleoli) (Figure 3c). The slight basophilic ooplasm were contained in several inclusions. The oil droplets and cortical alveoli were first dispersed at the periphery of the oocyte (Figure 2c). Empty vacuoles of the oil droplet were negatively stained in preparations stained with $\mathrm{H} \& \mathrm{E}$ and PAS methods (Figures 3c-d). The function of this inclusion concern with energy sources to developing embyo (Wiegand, 1996). The cortical alveoli were spherical in shape at the periphery of the ooplasm, showing varying size in diameters (10-15 in diameters). This inclusion reacted positively with $\mathrm{PAS}$ and $\mathrm{AB}$ stains, indicating the presence of the glycoprotein and mucopolysaccharide (Figures $3 \mathrm{~d}$ and $4 \mathrm{~d}$ ). Literature reviews suggested the role and function of the cortical alveoli concern with physiological function especially the prevention of polyspermy after ovulation (Nagahama, 1983). At this stage, the follicular complex was initially well defined and clearly consisted of three layers including the zona pellucida, granulosa cell and theca cell (Figures. 3c-d). The thin layer of zona pellucida was clearly seen as a cellular acidophilic structure and was found between the oocyte and follicular cells (Figures 3c-3d). The acidophilic fibrils were locally seen between single layers of granulose cells and theca cells in various positions (Figure 3e). Similar fibril composition occurred in Danio rerio (Patiño et al., 2003). Previous studies provided conflicting data about the function of the fibril. However, some investigators suggested that it may help to prevent water loss during low tide (Dumont and Brummet, 1980) .
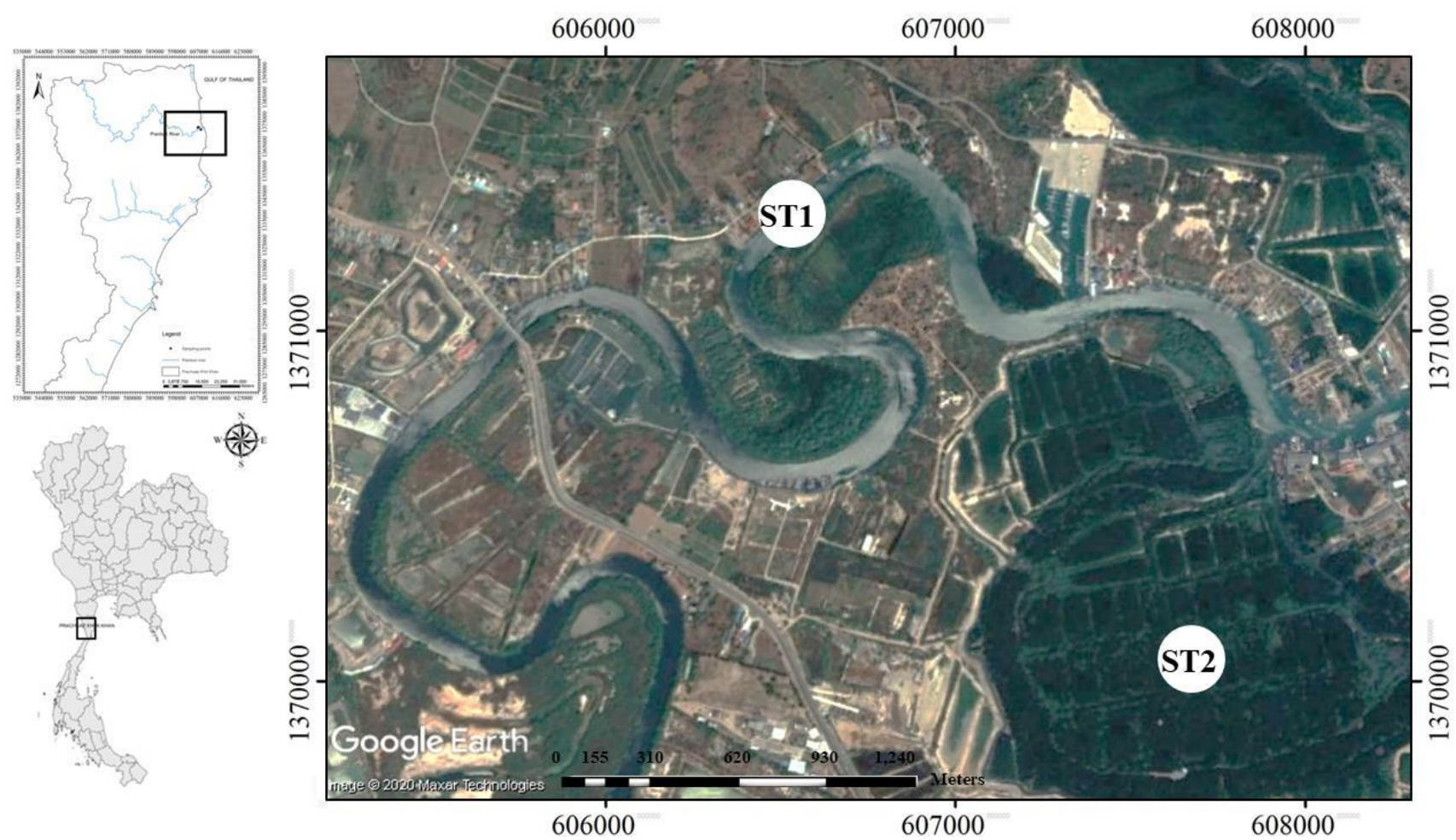

Figure 1. Sampling sites of Neostethus lankesteri in Pranburi River estuary (ST1, ST2), Pranchuap Khiri Khan Province. 

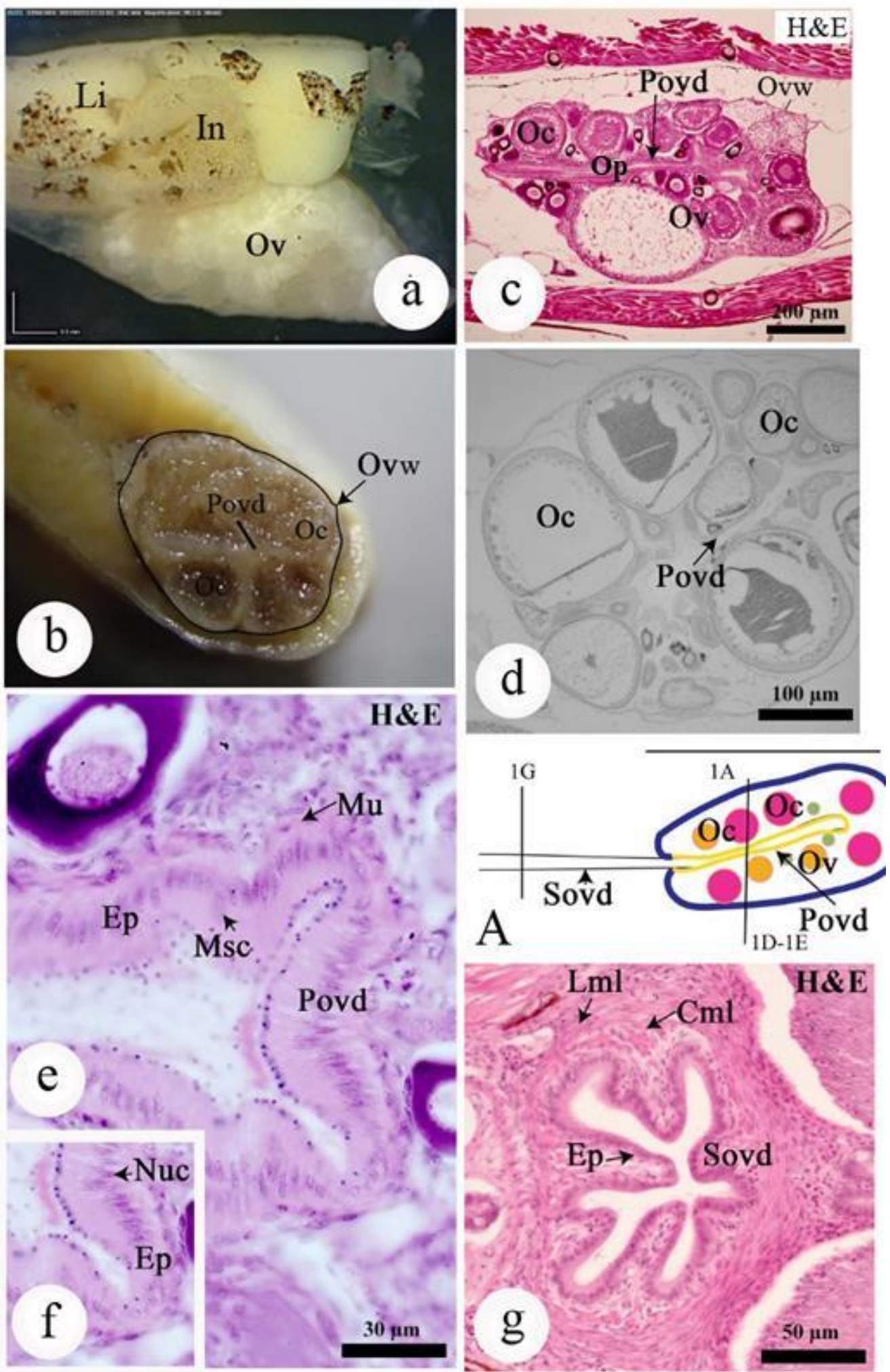

Figure 2. Morphology and photomicrographs of the ovarian structure in Neostethus lankesteri. a: Overall localization of ovary $(\mathrm{Ov})$ as seen under intestine (In) and liver (Li). b-d: Cross section (b) and light microscope (c-d) of the ovary with various developing oocytes (Oc) ovarian parenchyma (Op) and primary oviducts (Povd). A, e-f: Overview schematic diagram the primary oviduct (Povd) composed of the epithelium (Ep) and mucous cell (Msc), which was surrounded with a thin layer of muscularis (Mu). a, g: Overview schematic diagram the second oviduct (Sovd) consisted of epithelium (Ep) with covering in two distinct muscular layers including circular muscularis layer $(\mathrm{cml})$ and longitudinal muscularis layer (Lml). Abbreviations: Nuc $=$ nucleus. Staining method: H\&E $=$ Hematoxylin and Eosin. 

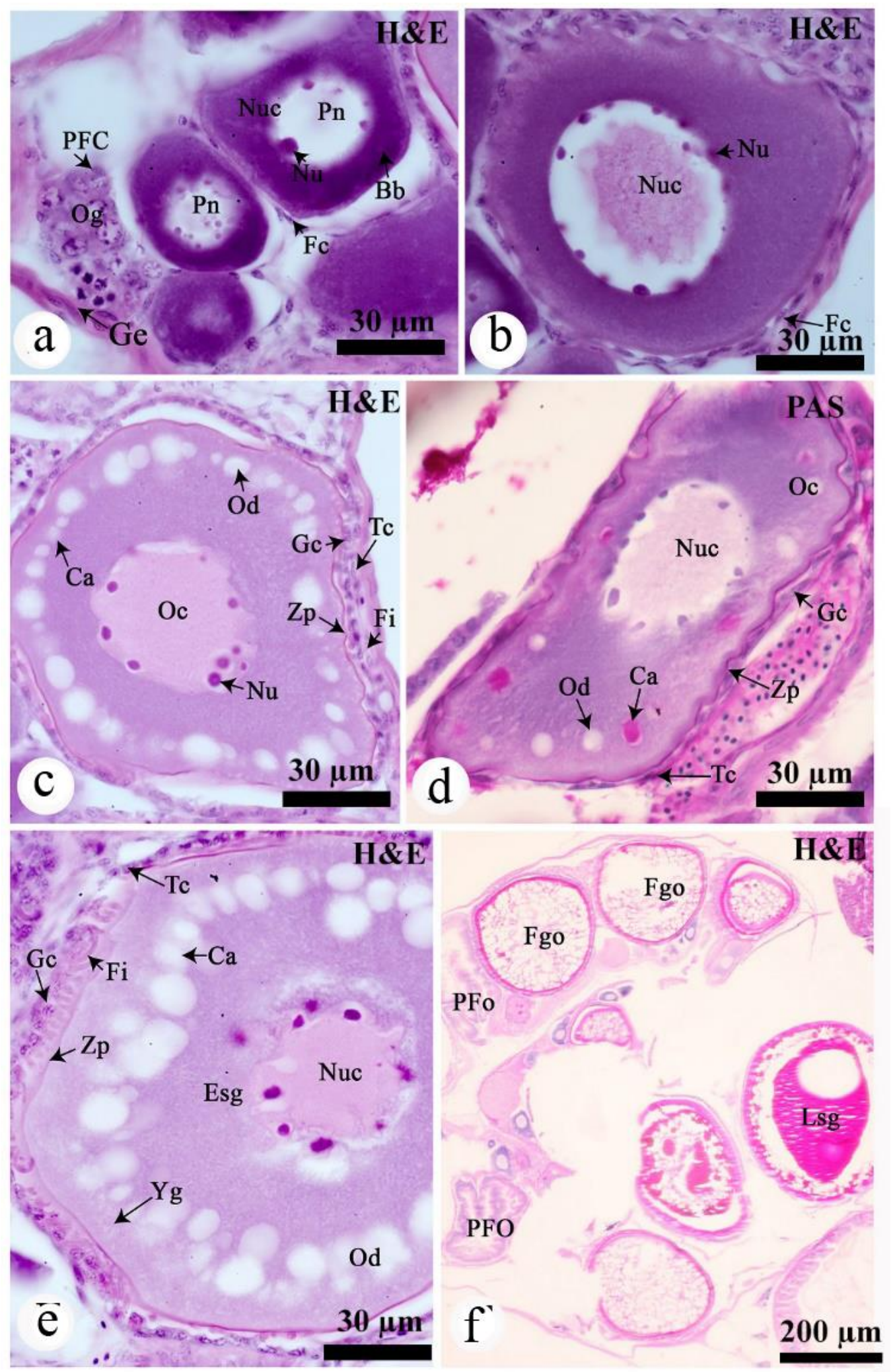

Figure 3. Light photomicrograph of the developing stage of oocytes in Neostethus lankesteri. a: Oogonia. b: Perinuceolar stage (Pn). c-d: oil droplet and cortical alveolar stage (Oc). e: early secondary growth step (Esg). f: late secondary growth step (Lsg), Full-grown oocyte step (Fgo) and post-ovulatory follicle (POF). Abbreviations: $\mathrm{Bb}=$ Balbiani's body, $\mathrm{Ca}=$ cortical alveoli, $\mathrm{Fc}=$ follicular cell, $\mathrm{Fi}=$ fibril, $\mathrm{Gc}=$ granulosa cell, $\mathrm{Ge}=$ germinal epithelium, $\mathrm{Nuc}=$ nucleus, $\mathrm{Nu}=$ nucleolus, $\mathrm{Od}=$ oil droplet, $\mathrm{PFC}=$ pre-follicular cell, $\mathrm{Tc}=$ theca cell, $\mathrm{Yg}=$ yolk granule, $\mathrm{Zp}=$ zona pellucida. Staining methods: $\mathrm{H} \& \mathrm{E}=$ Hematoxylin and Eosin, PAS = Periodic Acid Schiff. 


\section{Secondary growth phase}

This phase could be found in three stages of oocyte in the mature ovaries including early secondary growth step (Esg), late secondary growth step (Lsg) and full-grown oocyte step (Fgo).

The Esg oocytes had increased in size reaching diameters of $97 \mu \mathrm{m}$. The histological structure of the nucleus was obviously folded (Figure 3e). A major character noticed was that the small yolk granules were observed in both spherical and showed deeply acidophilic stain in the ooplasm (Figure 3e). They began to accumulate at the oocyte periphery, as previously found in most fishes (Chen et al., 2006). This material inclusion was stored during the secondary growth stage (Wallace and Selman, 1990) and is generally related to support the embryonic development as major source of the nutrition and metabolic activities in most fish species (Chen et al., 2006). The oil droplets and cortical alveoli remained, but these inclusions progressively increased in size $[5-10 \mu \mathrm{m}$ for oil droplet and 10-15 $\mu \mathrm{m}$ for cortical alveoli] (Figure $3 e)$. The zona pellucida was well differentiated, distinctly striated and increased further in thickness, attaining 12-14 $\mu \mathrm{m}$ in height (Figure $3 \mathrm{e})$. The increasing number of acidophilic fibrils was well defined (Figure 3e). The granulosa cell remained as a single layer; however its shape changed from squamous to low columnar epithelium (Figure 3e). A layer of theca cells was also similarly exhibited as in the prior stages.

The Lsg oocytes increased in size, up to 149 $\mu \mathrm{m}$ in diameter, when compared to other oocyte stages (Figures 3f, 4a). A similar pattern was seen in Hemiramphus brasiliensis and H. balao, which are both marine fishes (Mcbride and Thurman, 2003). Some areas of ooplasm initially revealed the yolk granules fusion (Figures 4a-4d). The cortical alveoli were positively with bluish structure and widely distributed in the ooplasm (Figure 4d). The zona pellucida with striated structure was observed (Figure 4b). The layers of the granulosa and theca cells remained single, but they were not different from the previous stage (Figure 4b).

The Fgo oocytes were observed at the end of the oogenic process, being considered as the largest oocytes, reaching a diameter of $218 \mu \mathrm{m}$ (Figure 3f). No nucleus was observed. The yolk globules were fused completely and stained negatively with H\&E stain (Figure 4d). The layer of follicular cells (granulosa and theca cells) and acidophilic fibrils were in the same position, but they were well developed (Figure 4d).

\section{Post-ovulatory phase}

Post-Ovulatory Follicular Complex (POC) was observed in $N$. lankesteri ovaries. They are composed of follicular layers, referring to the layers of the granulosa and theca cell. They are the remaining structure in the fish ovary after the release of the mature oocyte during spawning (Figure 3f). The fact that all ovarian developmental stages and the post-ovulatory stage were observed in this study suggested that $N$. lankesteri spend their entire life cycle in the estuary, which could infer that they are true estuarine species.

\section{Atretic follicle phase}

Atretic follicles were detected in $N$. lankesteri throughout the study, especially during secondary growth phase (Figures 4e-4f). This stage is characterized by irregular oocyte shape and convoluted layers of granulosa cells forming inside the atretic follicle cell. Previous observations revealed that the occurrence of the atretic follicle in teleosts can be related to stress and other environmental conditions e.g., insufficient nutrition, physical factors, hormones and chemical factors (Dietrich and Kreger, 2009).

\section{Ovarian development}

In $N$. lankesteri with standard length of $1.5 \mathrm{~cm}$, the ovary was found in the abdominal cavity. The primary growth phase (perinucleolar stage) was arranged around the ovarian structure. The ovary of $N$. lankesteri with standard length of $1.6-1.7$ $\mathrm{cm}$ was similar to the previous stage. The primary growth phase including the perinucleolar stage and cortical alveolar stage was found in the ovarian structure (Figures 5a-5c). The ovary of $N$. lankesteri $(1.8-1.9 \mathrm{~cm} \mathrm{SL})$ was similarly filled up as in previous stage. However, the beginning of secondary growth phase was found with two differential stages of oocytes including early secondary growth stage and late secondary growth stage detected in this size (Figures $5 \mathrm{~d}-5 \mathrm{f}$ ). In $N$. lankesteri fish with SL of $2.0-2.2 \mathrm{~cm}$, the ovary had similar patterns as in the previous stages with the presence of the primary growth and secondary 
growth stages. However, the additional and fullgrown oocyte stages were also observed (Figures $5 \mathrm{~g}-5 \mathrm{l})$. In fish with $2.3-2.4 \mathrm{~cm} \mathrm{SL}$, the ovary had the same pattern as in previous stages with the presence of the primary growth, secondary growth phases and the full-grown oocyte. However, atretic follicle oocytes were also observed (Figures 5m-5o). Therefore, this study suggested that the fish at $1.8 \mathrm{~cm}$ SL was the size of first maturity.

The present study described an overview of the gametogenesis of $N$. lankesteri for the first time, representing comprehensive information for fish from the genus Phallostethidae. In female fish, the mature ovary is from an asynchronous development oocyte type, consisting of two phases: primary growth phase (perinucleolar and oil droplet and cortical alveolar stages) and secondary growth phase (early vitellogenic, late vitellogenic and mature stages). Moreover, a postovulatory phase was also observed in sampling periods, which for the first time, indicates that $N$. lankesteri was spending their entire life in the Pranburi River estuary as true resident species.

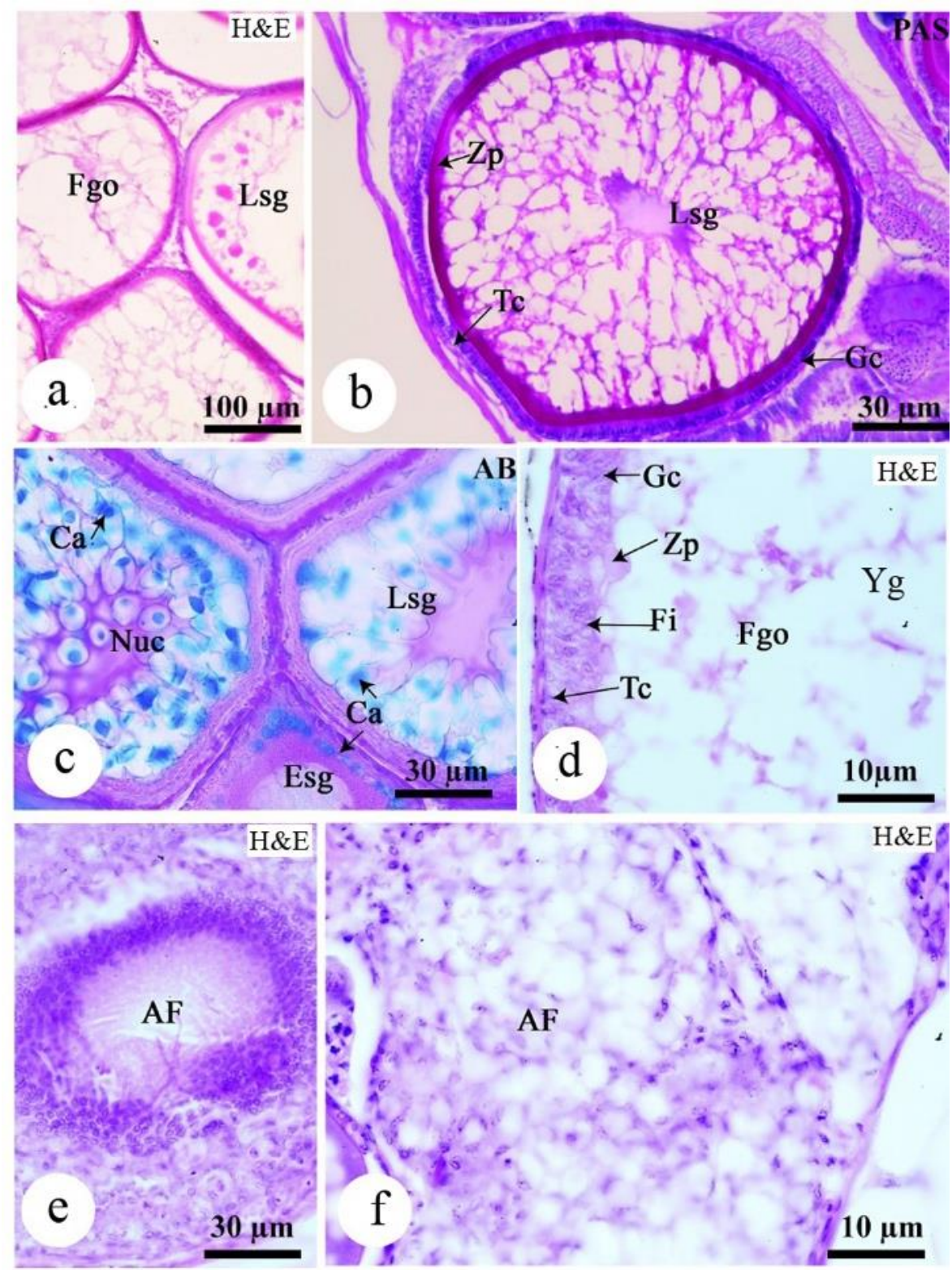

Figure 4. Light photomicrograph of various developing oocytes in Neostethus lankesteri. a-b: Late secondary growth (Lsg). c: The positive reaction as bluish of cortical alveoli (Ca) in late secondary growth (Lsg). d: full growth oocyte (Fgo). e-f: atretic follicle (AF). Abbreviations: $\mathrm{Fi}=$ fibrils, $\mathrm{Gc}=$ granulosa cell, Nuc $=$ nucleus, $\mathrm{Tc}=$ theca cell, $\mathrm{Zp}=$ zona pellucida. Staining methods: $\mathrm{H} \& \mathrm{E}=$ Hematoxylin and Eosin, $\mathrm{AB}=$ Alcian Blue, PAS = Periodic Acid Schiff. 

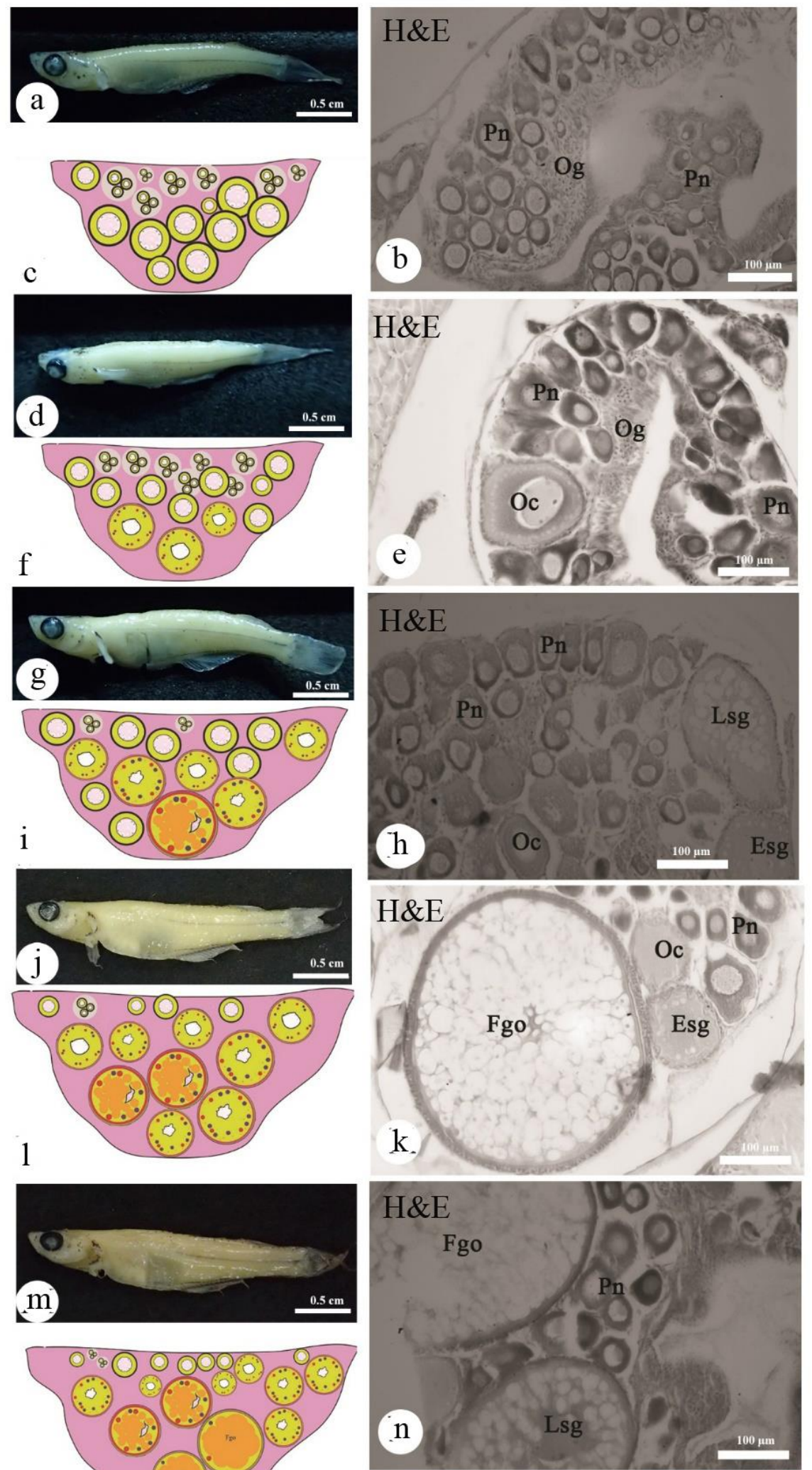

$\mathrm{O}$

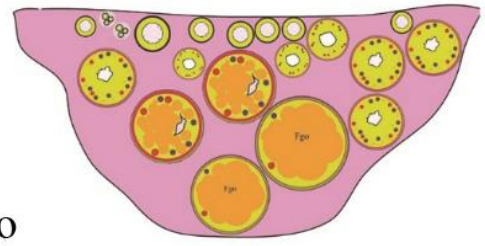

(n)

Figure 5. Image of whole fish, photomicrographs and schematic diagrams of the ovarian differentiation through different standard lengths (SL) in Neostethus lankesteri. a-c: SL of $1.6-1.7 \mathrm{~cm}$. d-f: SL of $1.8-1.9$ cm. g-h: SL of $2.0-2.2 \mathrm{~cm}$. M-O: SL of $2.3-2.4 \mathrm{~cm}$. Abbreviations: Esg = early secondary growth, Fgo $=$ Full-grown oocyte step, $\mathrm{Lsg}=$ late secondary growth step, Oc $=$ oil droplet and cortical alveolar stage, $\mathrm{Og}=$ oogonia, $\mathrm{Pn}=$ perinucleolar stage. Staining method: H\&E $=$ Hematoxylin and Eosin. 


\section{Male reproductive pattern}

The mature testis is a single and unpaired organ (Figures 6a-6b), which is elongated and suspended from the dorsal peritoneum.

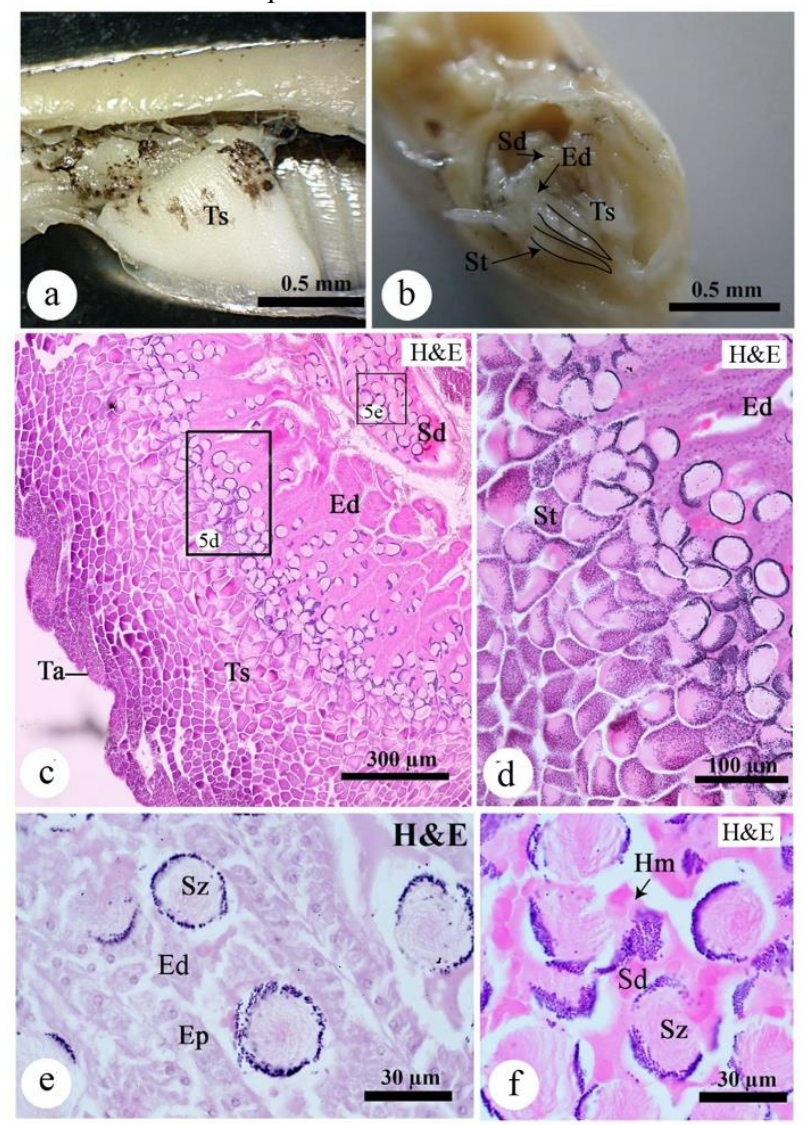

Figure 6. Characterization of the testicular structure in Neostethus lankesteri. a: Localization of the testicular structure (Ts). b: Morphology of the male reproductive system consisted of testicular structure with containing in several seminiferous tubule (St), efferent duct (Ed) and spermatic duct (Sd). c-d: Light microscope showing the testicular structure (Ts), efferent duct (Ed) and spermatic duct (Sd). e: High magnification showing the spermatozeugmata $(S z)$ in the efferent duct $(\mathrm{Ed})$. $\mathrm{f}$ : High magnification showing the spermatozeugmata $(\mathrm{Sz})$ among a homogenous eosinophilic matrix $(\mathrm{Hm})$ in the spermatic duct (Sd). Abbreviations: $\mathrm{Ep}=$ epithelium, $\mathrm{Ta}=$ tunica albuginea. Staining method: H\&E = Hematoxylin and Eosin.

The testis is surrounded by a tunica albuginea (Figure 7c) that emits septa of prominent connective tissue, blood vessels and a few layers of smooth muscle to the interior of the testis, forming the testicular parenchyma, which is composed of two regions, testicular structure and a well-developed efferent duct system (Figures 6c6d). It is similar to Phenacostethus smithi ( Munro and Mok, 1990; Grier and Parenti, 1994; Grier and Parenti, 1994).

Several seminiferous tubules were identified in the testicular structure and each tubule was jointed to form the efferent duct and spermatic duct at the posterior region of the gonad (Figures $6 \mathrm{~b}$ and $6 \mathrm{~d})$. The efferent duct is lined by a simple columnar epithelium and stores the spermatozoa (Figure 6e). A thin layer of the muscularis is also found. The covering epithelium of the spermatic duct is similar in the efferent duct; however, its lumen is embedded in a homogenous eosinophilic matrix (Figure 6f). This substance may be secreted from the epithelium to support the sperm maturation. The function of the spermatic duct is therefore carrying mature sperm towards the vas deferens during spermiation (Dietrich and Krieger, 2009).

The schematic diagram and histological images of testicular structure in this fish was classified into two compartments, including germinal compartment (or seminiferous tubule) and interstitial compartments (Figures 7a-7c). The interstitial compartment protrudes from the tunica albuginea, and is not easily identified under light microscopy. TEM methods, on the other hand clearly showed that Leydig cells had an oval shape and are present as single or cluster cells (Figures $7 \mathrm{e}$ and $7 \mathrm{~d}$ ), and were located near the germinal cyst (Figure 8d), as previously observed by Nagahama (1983) and Billard (1992). The welldeveloped mitochondrial was seen within the cytoplasm of the Leydig cell (Figure 8e). The Leydig cell is considered to be the androgenproducing cell in male fish, as confirmed in Synbranchus senegalensis, Padogobius martensi (Cinquetti and Dramis, 2003) and S. marmotatus (Nostro et al., 2004).

The spermatogonial phase is composed of different generations of spermatogonia that undergo mitotic divisions. Spermatogonia could be divided into two types: type $\mathrm{A}$ and type $\mathrm{B}$ spermatogonia (Figure 8a). Type A spermatogonia is locally seen in the distal end of the lobule of the testis. It presents a large nucleus with a single nucleolus, surrounded by light granular cytoplasm. It is believed this cell type acts as a stem cell (Dietrich and Krieger, 2009). Type B spermatogonia are smaller than type A 
spermatogonia. They replicated their chromosomes under mitoses before entering the spermatocytary phase.

The spermatocytephase is produced segregated by meiotic divisions, which divided into two cell cycles (primary and secondary spermatocytes) (Figure 8a). The primary spermatocyte is ovoid and smaller compared to the spermatogonium. The gradual clumping of nuclear chromatins and the disappearance of nucleolus were identified in this stage.
Eosinophilic cytoplasm was restricted around their nucleus (Albert et al., 1994; Schlz et al., 2010). The secondary spermatocyte was produced under meiosis I from the primary spermatocyte, therefore it was smaller than the primary spermatocytes (Schlz et al., 2010). The nucleus of secondary spermatocytes was stained basophilic surrounded by scanty cytoplasm (Figure 8a). The duration of this stage is short in most teleosts (Nagahama, 1983; Billard, 1992).
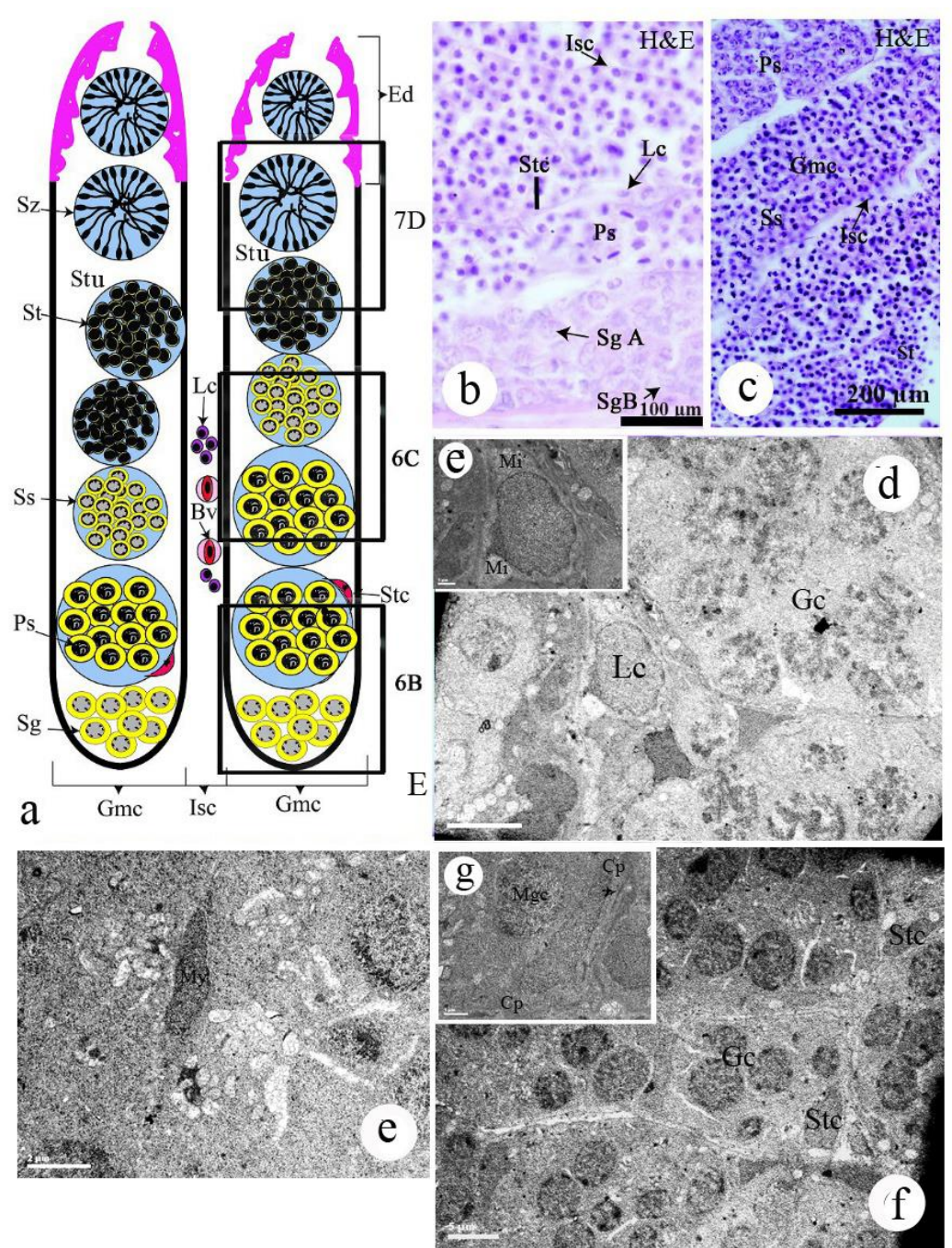

Figure 7. Observation of the seminiferous tubules and spermatogenesis in Neostetbus lankesteri. a: Schematic diagram of the testicular tissue composed of two compartments including interstitial compartment (Isc) and germinal compartment (Gmc). Within the Gmc, it contained in the different stages of sperm including spermatogonium ( $\mathrm{Sg}$ ), primary spermatocytes $(\mathrm{Ps})$, secondary spermatocytes ( $\mathrm{Ss}$ ), spermatids (St) and spermatozeugmata $(\mathrm{Sz})$. b-c: Ligh microscope showing the spermagonium type A $(\mathrm{SgA})$, spermagonium type B ( $\mathrm{SgB})$, secondary spermatocytes $(\mathrm{Ss})$ in the Gmc. d-e: Electron microscope showing the leydig cell (Lc) near the germinal cyst. F: Electron microscope showing the perilobular myeloid cell (My). g-h: Electron microscope showing Sertoli cell (Stc) in close to germinal cyst (Gc). Abbreviations: $\mathrm{Bv}=$ blood vessel, $\mathrm{Cp}=$ cytoplasmic process, $\mathrm{Ed}=$ efferent duct, $\mathrm{Mi}=$ mitochondria, Stu $=$ seminiferous tubule. Staining method: H\&E $=$ Hematoxylin and Eosin. 
In the spermiogenic phase pass through morphological and functional changes which are related to the differentiation of spermatids in spermatozoa. The spermatid showed a high nuclear condensation (Figure 8b). Scant eosinophilic cytoplasm is also observed. It is agreed in some fish (Schlz et al., 2010). Spermatozeugmata is the smallest cell among the spermatogenic cells (Figure 8b). Under a light microscope, both the packed head and tail of the spermatozoa were clumped together (Figure 8b), as seen in members of the genus Zenarchopterus (Grier and Collete, 1987).

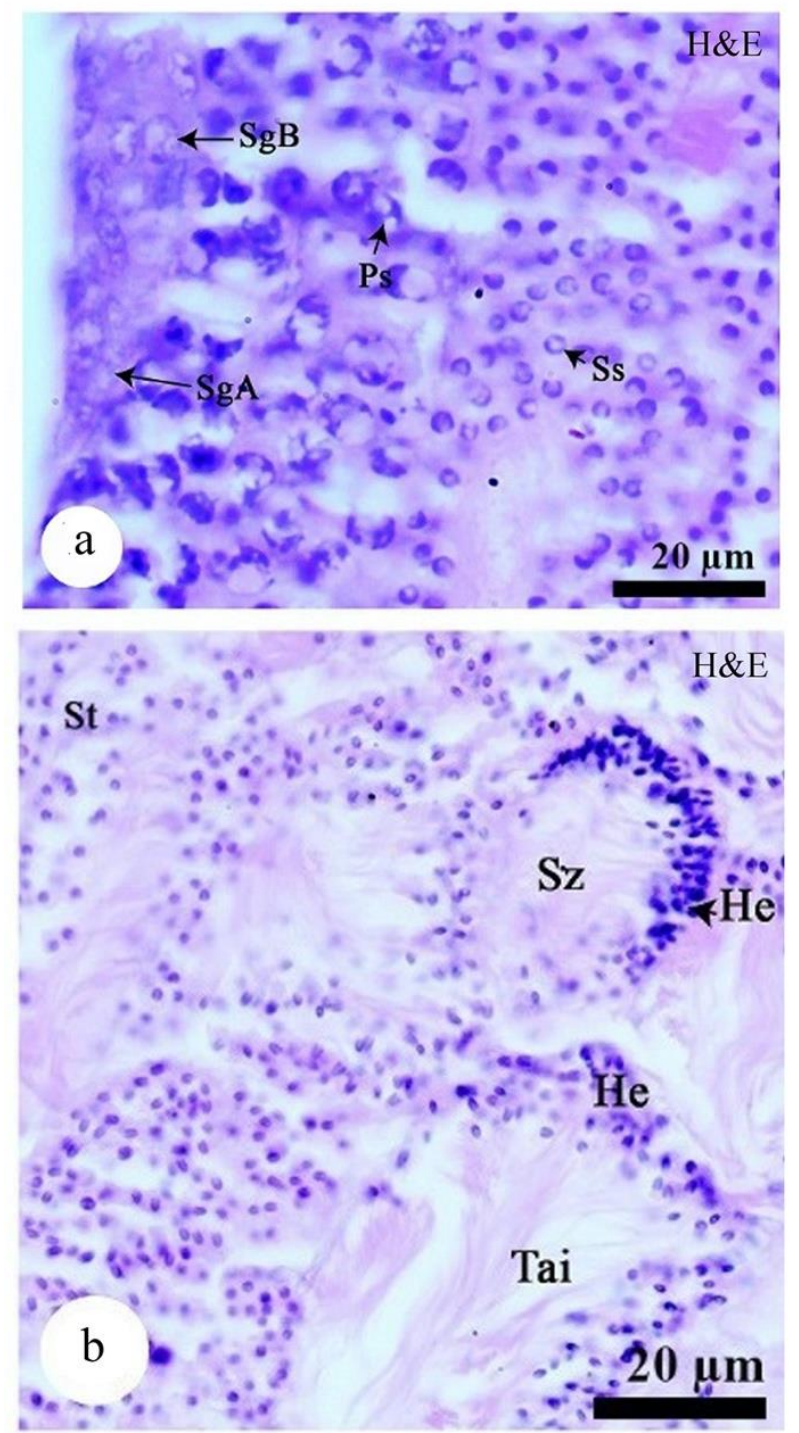

Figure 8. High magnification images of different stages of spermatogenesis. a: Spermagonium type A (SgA), spermagonium type B ( $\mathrm{SgB})$ and secondary spermatocytes (Ss). b: Spermatids (St) and spermatozeugmata $\left(\mathrm{S}_{z}\right)$ are very small. $\mathrm{Sz}$ showed packed head of spermatozoa $(\mathrm{He})$ and tail
(Tai). Staining: $\mathrm{H} \& \mathrm{E}=$ Staining method: $\mathrm{H} \& \mathrm{E}=$ Hematoxylin and Eosin.

\section{ACKNOWLEDGMENTS}

This research was exclusively funded by the $90^{\text {th }}$ Anniversary of Chulalongkorn University Fund (Ratchadaphiseksomphot Endowment Fund). We thank the Fish Biology and Aquatic Health Assessment Laboratory (FBA-LAB), Department of Marine Science, Faculty of Science, Chulalongkorn University for their support throughout this study. We also thank Dr. Todd Miller for reading the spelling and the grammatical structure in this manuscript. The experimental protocol was approved by the Animal Care and Use Committee of Faculty of Science, Chulalongkorn University (Protocol Review No. 1523005).

\section{REFERENCES}

Alberts, B., Johnson, A. D., Lewis, J., Morgan, D., Raff, M., Roberts, K., \& Walter, P., 2014. Molecular Biology of the Cell. $6^{\text {th }}$ ed. New York, W.W, Norton \& Company.

Billard, R. 1992. Reproduction in rainbow trout: sex differentiation, dynamics of gametogenesis, biology and preservation of gametes. Aquaculture 100: 263-298.

Brown-Peterson, N. J., Wyanski, D. M., Saborido-Rey, F., Macewicz, B. J., \& Lowerre-Barbieri, S. K. 2011. A standardized terminology for describing reproductive development in fishes. Marine and Coastal Fisheries 3: 52-70.

Chellappa, S., Lima, J., Araújo, A., \& Chellappa, N. 2010. Ovarian development and spawning of Serra Spanish mackerel in coastal waters of Northeastern Brazil. Brazilian Journal of Biology 70: 451-456.

Chen, K. S., Crone, P., \& Hsu, C. C. 2006. Reproductive biology of female Pacific bluefin tuna Thunnus orientalis from southwestern North Pacific Ocean. Fisheries Science 72: 985-994.

Cinquetti, R. \& Dramis, L. 2003. Histological, histochemical, enzyme histochemical and ultrastructural investigations of the testis of Padogobius martensi between annual breeding seasons. Journal of Fish Biology 63; 1402-1428.

Chakrabarti, P. \& Banerjee, A. S. 2015. Histological findings and seasonal distribution of different germ cells in the testicles of freshwater needle fish, Xenentodon cancila (Hamilton). International Journal of Fisheries and Aquatic Studies 2: 74-80.

Dietrich, D. \& Krieger, H. O. 2009. Histological Analysis of Endocrine Disruptive Effects in Small Laboratory Fish. New Jersey, John Wiley \& Sons.

Dumont, J. N. \& Brummet, A. R. 1980. The vitelline envelope, chorion, and micropyle of Fundulus heteroclitus eggs. Molecular Reproduction and Development 3: 25-44.

Grier, H. J. \& Collette, B. B. 1987. Unique Spermatozeugmata in Testes of Halfbeaks of the Genus Zenarchopterus (Teleostei: Hemiramphidae). Copria 2: 300-311. 
Grier, H. J. \& Parenti, L. R. 1994. Reproductive biology and systematics of phallostethid fishes as revealed by gonad structure. Environmental Biology of Fishes 41: 287-299.

Gupta, S. 1975. The development of carp gonads in warm water aquaria. Journal of Fish Biology 7: 775-782.

Hamaguchi, S. 1993. Alterations in the morphology of nuages in spermatogonia of the fish, Oryzias latipes, treated with puromycin or actinomycin D. Reproduction Nutrition Development 33: 137-141.

Hara, M. \& Okiyama, M. 1998. An ultrastructural review of the spermatozoa of Japanese fishes. Bulletin of the Ocean Research Institute, University of Tokyo 33: 1-138.

Kuchnow, K. P. \& Scott, J. R. 1977. Ultrastructure of the chorion and its micropyle apparatus in the mature Fundulus beteroclitus (Walbaum) ovum. Journal of Fish Biology 10: $197-$ 201.

Lacerda, S. M. S. N., Martinez, E. R. M., Mura, I. L. D. D., Doretto, L. B., Costa, G. M. J, Silva, M. A., Digmayer, M., Nóbrega, R. H., \& França, L. R. 2018. Duration of spermatogenesis and identification of spermatogonial stem cell markers in a Neotropical catfish, Jundiá (Rhamdia quelen). General Comparative and Endodocrine. In press.

Ling, J. 1958. The Sea Garfish, Reporhamphus melanochir (Cuvier \& Valenciennes) (Hemi-ramphidae), in South Australia: Breeding, age determination, and growth rate. Marine and Freshwater Research 9: 60-110.

Mattei, X. 1991. Spermatozoon ultrastructure and its systematic implications in fishes. Canadian Journal of Zoology 69: 30383055.

Mayer, I., Shackley, S. E., \& Ryland, J. S. 1988. Aspects of the reproductive biology of the bass, Dicentrarcbus labrax L. I. An histological and histochemical study of oocyte development. Journal of Fish Biology 33: 609-622.

McBride, R. S. \& Thurman, P. E. 2003. Reproductive biology of Hemiramphus brasiliensis and $H$. balao (Hemiramphidae): Maturation, spawning frequency, and fecundity. Biological Bulletin 204: 57-67.

McMillan, D. B. 2007. Fish Histology: Fish Reproductive System. Dordrecht. Springer Netherlands.

Mok, E. M. \& Munro, A., 1997. Some anatomical and behavioural aspects of reproduction in members of an unusual teleost family: the Phallostethidae. Journal of Natural History 31: 739778.

Munro, A. D. \& Mok, E. Y. M. 1990. Occurrence of the phallostethid fish Phenacostethus smithi Myers in southern Johor, Peninsular Malaysia, with some observations on its anatomy and ecology. Reffles B. Zoology 38: 219-239.

Nagahama, Y. 1983. The functional morphology of teleost gonads. In: Fish Physiology. Eds. Hoar, S., Randall, D.J. and Donaldson, E.M. pp. 223-275. Academic Press, Orlando: FL.V.

Neidig, C. L., Skapura, D. P., Grier, H. J., \& Dennis, C. W. 2000. Techniques for spawning common snook: Broodstock handling, oocyte staging, and egg quality. North American Journal of Aquaculture 62: 103-113.

Nostro, F. L. L., Antoneli, F. N., Quagio-Grassiotto, I., \& Guerrero, G. A. 2004. Testicular interstitial cells, and steroidogenic detection in the protogynous fish, Synbranchus marmoratus (Teleostei, Synbranchidae). Tissue and Cell 36: 221-231.

Paphavasit, N., Siriboon, S., Jaiperm, J., \& Mookui, P. 2014. Sirinath Rajini Mangrove Ecosystem Learing Center. From mangrove plantation to mangrove forest enhaching human development (1 ed.): Bangkok: PTT co., Ltd and Department of Science, Chulalongkorn University.

Parenti, L. R. 1984. On the relationships of phallostethid fishes (Atherinomorpha): with notes on the anatomy of Phallostethus dunckeri Regan, 1913. American Museum novitates; no. 2779.

Parenti, L. R. \& Grier, H. J. 2004. Evolution and phylogeny of gonad morphology in bony fishes. Integrated Comparative Biology 44: 33-348.

Patiño, R., Wainscott, M. R., Cruz-Li, E. I., Balakrishnan, S., McMurry, C., Blazer, V. S., \& Anderson, T. A. 2003. Effects of ammonium perchlorate on the reproductive performance and thyroid follicle histology of zebrafish. Environmental Toxicology and Chemistry 22: 1115-1121.

Presnell, J. K. \& Schreibman, M. P. 1997. Humason's Animal Tissue Techniques, Johns Hopkins University Press.

Redding, J. \& Patino, R., 2000. Reproductive systems: Gross functional anatomy. The Handbook of Experimental Animals. In: The Laboratory Fish. Ed. Ostrander, G.K. pp.261-272. Academic Press: San Diego, CA.

Schulz, R. W., De França, L. R., Lareyre, J. J., LeGac, F., ChiariniGarcia, H., Nobrega, R. H., \& Miura, T. 2010. Spermatogenesis in fish. General Comparative and Endocrinology 165: 390-411.

Selman, K. \& Wallace, R. A. 1989. Cellular aspects of oocyte growth in teleosts. Zoological Science 6; 211-231.

Senarat, S., Kettratad, J., \& Jiraungkoorskul, W. 2018. Testicular structure and spermatogenesis of short mackerel, Rastrelliger brachysoma (Bleeker, 1851) in Upper Gulf of Thailand. AsiaPacific Journal of Molecular Biology and Biotechnology 26: 30-43.

Suvarna, K. S., Layton, C., \& Bancroft, J. D. 2013. Bancroft's Theory and Practice of Histological Techniques: Canada, Elsevier.

Uribe, M. C., Grier, H. J., \& Mejia-Roa, V. 2014. Comparative testicular structure and spermatogenesis in bony fishes. Spermatogenesis 4: e983400.

Uribe, M. C., Grier, H. J., \& Parenti, L. R. 2012. Ovarian structure and oogenesis of the oviparous goodeids Crenichthys baileyi (Gilbert, 1893) and Empetrichthys latos Miller, 1948 (teleostei, Cyprinodontiformes). Journal of Morphology 273: 371-387.

Wallace, R. A., \& Selman, K. 1981. Cellular and dynamic aspects of oocyte growth in teleosts. American Zoology 21: 325-343.

Wallace, R. A., \& Selman, K. 1990. Ultrastructural aspects of oogenesis and oocyte growth in fish and amphibians. Microscopy Research and Technique 16: 175-201.

Wiegand, M. D. 1996. Composition, accumulation and utilization of yolk lipids in teleost fish. Reviews in Fish Biology and Fisheries 6: 259-286.

Wilson, J. M., Bunte, R. M., \& Carty, A. J. 2009. Evaluation of rapid cooling and tricaine methanesulfonate (MS222) as methods of euthanasia in zebrafish (Danio rerio). Journal of the American Association for Laboratory Animal Science 48: 785-789. 